\title{
Correlates of Stock Market Development and Economic Growth: A Confirmatory Study from Ghana
}

\author{
Edward Alabie Borteye ${ }^{1}$ \& Williams Kwasi Peprah ${ }^{2}$ \\ ${ }^{1}$ Ministry of Finance and Economic Planning, Accra, Ghana \\ ${ }^{2}$ Valley View University, School of Business, Oyibi, Accra, Ghana \\ Correspondence: Williams Kwasi Peprah, Valley View University, School of Business, Oyibi, Accra, Ghana. Tel: \\ 233-277-510-447.
}

Received: December 20, 2021

Accepted: January 10, 2022

Online Published: January 15, 2022

doi:10.5539/ijef.v14n3p1

URL: https://doi.org/10.5539/ijef.v14n3p1

\begin{abstract}
The study confirms the debate on whether stock market development correlates to economic growth. The dimensions used for the stock market development consisted of market liquidity, size, and capitalization. Economic growth was represented by the real gross domestic product (GDP) growth rate. Based on secondary data obtained from the Ghana Stock Exchange (GSE) and Ghana Statistical Service from 2014 to 2018 , a correlational research design was adopted to analyze the data with SPSS 20v by using bivariate and regression. The study found that there is a high positive relationship between market liquidity and economic growth, a moderate negative relationship between market size and economic growth, and a moderate positive relationship between market capitalization and economic growth. Also, the stock market development of market liquidity, size, and capitalization predict 95.7 percent of economic growth. The study summarized that there is a high positive association between stock market development and economic growth as a confirmatory revelation, but all the relationship results were not statistically significant. The result points to the casualty of the relationship between stock market development and economic growth. The study recommends that more firms must be encouraged to be listed on GSE to enhance economic growth in Ghana.
\end{abstract}

Keywords: stock market development, economic growth, market liquidity, market size, market capitalization

\section{Introduction}

The financial system creates a more natural way to trade goods and services, makes savings accessible for individuals and companies, allows resource allocation and corporate management to be regulated more effectively by capital markets and permits risk pooling (Ngare, Nyamongo, \& Misati, 2014). If there are capital and commercial institutions, business and savings banks, merchant banks or finance companies, the presence of financial intermediaries permits exchanges of cash assets and facilitate innovation, allow technology advancement, and accelerate growth for financial intermediaries. There is, therefore, an association between financial sector development and economic growth (Bayar, Kaya, \& Yildirim, 2014). With the ever-growing importance of stock markets, numerous studies have been carried out worldwide to investigate the relationship between stock market development and economic growth (Dike, 2016).

The finance-growth nexus has been extensively debated in both theoretical and empirical literature. The debate has shown several dimensions, one of which is whether or not the creation of the stock market promotes growth (Pan \& Mishra, 2018). However, due to the underdevelopment of the African capital markets, the debate was largely confined to the association between banking sector development and economic growth (Guillén \& Capron, 2016). This has contributed to a situation of patchy and inchoate information on the stock markets that contributed to the development of African economies. Adu, Marbuah, and Mensah (2013) also reported that empirical studies on the finance-growth hypothesis are scanty in Ghana. This study seeks to narrow this gap by analyzing the relationship between Ghana's stock market development and the growth of the Ghanaian economy.

The purpose of the study is to add to the existing empirical literature on the finance-growth nexus in Ghana. Therefore, the relevance of this study lies in its contribution to the field of knowledge by providing information to confirm or contradict the findings of previous studies on the relationship between stock market development and economic growth in Africa. The study will be a source of useful information to policymakers and help them shape policies that will stimulate activities on the Ghana Stock Exchange and spur the growth of the Ghanaian 
economy.

According to Şükrüoğlu and Nalin (2014), it is widely recognized that stock market development is considered crucial to national economic growth since it: (a) offers an additional avenue for promoting and mobilizing domestic savings; (b) ensures improved investment efficiency through capital/resource allocation, and (c) improves managerial discipline via the market for corporate governance. The stock market has a strong impact on national investments, capital resource distribution, fund funding, and business opportunities and ultimately paves the way for economic development. The role of the stock market in the economic development market performance has a causal impact on economic growth. That is, financial institutions and markets are intentionally designed to increase the availability of financial services. The stock market raises liquidity and invests in more efficient ways to stimulate economic growth. This is termed the supply-leading hypothesis.

On the other hand, a causal association exists between economic growth and stock market development (Ho \& Iyke, 2017). In that view, the growth of the stock market appears as a function of economic development, which is a demand-following hypothesis. Continual economic growth demands more financial resources and new technologies. The financial system adapts to the real sector's financing needs and fits in with its autonomous growth (Ananwude \& Osakwe, 2017). This kind of performance of the stock market plays a very passive role in the growth cycle.

The third view also emphasizes the mutual relationship between the development of the stock market and economic growth (Srinivasan, 2014). Economic growth makes the development of a system of financial intermediation competitive, and the development of an effective capital market structure allows for faster economic growth (Srinivasan, 2014). Through engaging in fund pooling, risk diversification, and liquidity management, the capital market structure enhances capital allocation efficiency and increases the real-sector productive capacity.

At the same time, the technical output of the stock markets increases with its size because in financial intermediation activities, economies of scale and learning through acting effects are present (Ojo \& Ayadi, 2014). Consequently, the capital market can be influenced by the real sector through a favorable externality in the form of a volume of savings (Nyasha \& Odhiambo, 2017). Economic growth and stock market development, therefore, have positive impacts on each other in the development process.

Adusei (2014) did a study to analyze how Ghana's stock market contributes to the growth of the Ghanaian economy through quarterly data (2006Q1-2013Q2). For the study, a bounds co-integration testing method and Granger causality are used in the vector error correction model. The findings of the co-integration study indicate that there is a long-term co-integrating bond between stock market growth and economic development. The findings of the causality study suggest unidirectional causality from stock market development to economic growth. Nevertheless, as a negative correlation between the stock market and economic growth is seen in the long-term regression study, the study concludes that stock market development does not stimulate the growth of the Ghanaian economy. Adusei (2014) study ended in 2013; therefore, this study has found a gap in knowledge based on the period to confirm these results if it is the same as in 2018.

\subsection{Statement of the Problem}

The problem of this study is to examine the type of relationship that exists between stock market development and economic growth. The research focuses on the period from 2014 to 2018. The aim is to seek to confirm or contradict Adusei (2014) study on Ghana Stock Exchange development and economic growth.

\subsection{Research Objectives}

The objectives of this research are as follows:

1) To investigate the relationship between stock market liquidity and economic development.

2) To examine the link between stock market size and economic development.

3) To find the association of stock market capitalization and economic development.

4) To account for economic growth based on stock market size, liquidity, and capitalization.

\subsection{Research Questions}

The research questions for this study are as follows:

1) Is there a significant relationship between stock market liquidity and economic growth?

2) Is there a significant relationship between stock market size and economic growth? 
3) Is there a significant relationship between stock market capitalization and economic growth?

4) Which of the following predict economic growth
a. Market Size
b. Market Liquidity
c. Market Capitalization

\subsection{Hypothesis}

1) There is no significant relationship between stock market liquidity and economic growth.

2) There is no significant relationship between stock market size and economic growth.

3) There is no significant relationship between stock market capitalization and economic growth.

4) None of the following predicts economic growth
a. Market Size
b. Market Liquidity
c. Market Capitalization

\subsection{Significance of the Study}

This study will benefit the following group of people:

The Minister for Finance: The Minister for Finance in Ghana is responsible for ensuring solid and sound financial and economic development in Ghana. Therefore, this study will provide him with information on the relationship between stock market development and the growth of the Ghanaian economy. The result of the study will help the Minister in decision making about the economy of Ghana.

Chief Executive Officer of the Ghana Stock Exchange: The Ghana Stock Exchange (GSE) aims to ensure financial integration and economic development. This research will point out how GSE is impacting economic growth in Ghana. As a result, the Chief Executive can report on his role regarding the development of the Ghanaian economy.

Investment Analyst: Investment Analysts are the players on the GSE. They will be interested in finding out how their trading activities on the stock exchange impact the economic development in Ghana. Therefore, this study will be beneficial to them.

Future Researchers: The results and recommendations from this study can lead to further studies. Therefore, this study will be beneficial to future researchers, including academia.

\subsection{Scope and Limitation of the Study}

The study considered gross domestic product growth rate and three stock market dimension indicators from 2014 to 2018. This is the secondary data application of analysis. One limitation of this study is that the findings are best limited to the period covered under the research. Another limitation that may affect the result of this study is that it employs three indicators to measure stock market development and covers a five year period. However, some researchers use several indicators and a longer time period to produce better results. In view of these limitations, the findings should be treated with caution when using them in making generalizations.

\section{Review of Related Literature}

\subsection{Stock Market Development}

The development of stock markets is a multidimensional phenomenon. This is typically calculated by stock market size, liquidity, volatility, concentration, alignment with global capital markets, and the market legislations, regulations, and supervision (Owiredu, Oppong, \& Asomaning, 2016). Again, given the role that financial systems play in economic growth, current studies are aimed at associating stock markets with economic development.

The determinants of the stock market's growth in recent years have attracted the attention of many states, policymakers, market regulators, and scholars. (Owiredu, Oppong, \& Asomaning, 2016) used pooled data from 15 developed and developing countries to research the macroeconomic determinants of stock market growth from 1980 to 1995 and found that real income, savings rate, inflation, intermediate financial growth, and stock market liquidity play an important role in the stock market development.

Al-Malkawi et al. (2012) argue that financial development promotes investment change before continued 
contemporary economic growth is progressive, and, as current growth occurs, the supply-leading force is slowly becoming less important as demand dominates after financial response. Initially, one industry can be financially supported on a supply-leading basis, and its funding changes to demand as it grows, while another industry can remain in the supply-leading process.

Macroeconomic stability is important to the growth of stock markets. The stock market and the banking sector are complementary and not substitutes. A well-developed stock market is promoted by a combination of factors such as sound macroeconomic or fiscal policies, structural growth, and the availability of strong legal and regulatory structures (Tsaurai, 2018).

Ayunku and Etale (2015) investigated stock market development determinants for the period 1977-2010, using ex-post facto research design and the use of the Johansen Co-integration and error correction method. The empirical result shows that market capitalization, private sector credit, and exchange rates are significant determinants of Nigeria's long-term and short-term stock market growth.

\subsubsection{Stock Market Size}

According to Soderbery (2014), market capitalization calculates the size of the capital market and represents the value of domestic securities listed as a percentage of GDP. Though large markets do not always work efficiently and taxes may distort incentives for listing on the exchange, many analysts use capitalization as a measure of business growth. Since market size focuses on only one aspect, other elements of economic growth are taken into account in such assessments.

The size of the market is based on the ratio of stock market capitalization to the gross domestic product since it sums up the value of all listed shares in the stock market (Owusua \& Odhiamboa, 2014).

\subsubsection{Stock Market Liquidity}

Two related market liquidity interventions are used to measure the liquidity of the stock market (Switzer \& Picard, 2015). Firstly, stock market turnover equals the amount of domestic stock traded as a ratio of the amount of the domestic shares listed/market capitalization. Turnover is also used as a low-cost transaction measure. Notably, a large stock market is not always a liquid market: there would be a broad but inactive market with high capitalization but low turnover.

The second stock market liquidity indicator is value rated, which is equivalent to the value of shares traded as a percentage of GDP. Although not a clear measure of trading costs or the volatility associated with trading on a given exchange, theoretical models of liquidity on the stock market and economic growth directly promotes value traded (Erdogan, Bennett, \& Ozyildirim, 2015). Value traded calculates market volume as a share of national production and, thus, will positively reflect liquidity across the economy. Value traded can differ significantly from a turnover, as demonstrated by Chordia, Subrahmanyam, and Tong (2014). Whereas value traded tracks trade relative to economic size, the turnover measures trade relative to stock market value. Therefore, a low liquid market would have a high turnover, but little value exchanged.

Since financial markets are forward-looking, there is one possible pitfall in interest exchanged. If investors expect big profits for companies, stock prices rise. This price rise increases the value of stock purchases and boosts prices exchanged as a result. Problematically, the liquidity metric will grow without an increase in transaction numbers or a decrease in transaction costs (Switzer \& Picard, 2015). Capitalization often befalls this price impact. One way to gauge the price effect impact is to look at capitalization and traded value together. The price effect affects all metrics, but the only traded value is directly correlated with trading. Therefore, some studies use both capitalization and value traded metrics in the regression analysis.

If, when accounting for capitalization, value traded remains substantially associated with growth, then the price impact does not dominate the relationship between value traded and growth (Erdogan, Bennett, \& Ozyildirim, 2015). A second way to gauge the importance of the price effect is the turnover. The price effect does not affect turnover because stock values join the turnover numerator and denominator. If turnover is positively and robustly linked to economic growth, that means that the price effect does not dominate the liquidity-long-term economic growth relationship.

A stock market can be described as a financial institution that promotes capital formation and capital allocation competence. In addition, the stock markets allow government and private firms to fund their new ventures as well as develop, modernize, and expand commercial or industrial concerns by increasing long-term capital. Chatterjee (2015) argues that capital services should be given to industries that can increase the production and productivity of these industries. When the reverse occurs, the rate of economic growth will decline, thereby clearly showing that stock market creation is critical for economic growth and is viewed as having a favourable 
connection to economic growth. Corporate companies benefit from the stock market by offering long-term debt-funding and equity capital and a continuous source of funds for production and/or expansion, which has a positive effect on economic growth.

Kumar and Misra (2015) argue that liquid markets are of crucial importance to development. Most successful investments are long-term and require long-term capital commitment. Savers are risk-averse and unable to relinquish control of their savings capital for longer periods; equity markets can draw further investors because they offer assets that can be sold to savers easily and economically.

A liquid market enables savers to invest in long-run projects and also helps them to access their capital quickly before the project is finished and the profits are dispersed (Fidrmuc, Fungáčová, \& Weill, 2015). That can be done easily by selling their stock market claim. This means the more competitive the stock market, the lower the barriers to investing in long-run ventures. Liquidity on the stock exchange can also raise savings returns, provide viability, and probably cheaper funding for further investments in projects.

The stock market plays a crucial role in supplying investors and financial firms with a secondary market that would enable them to exchange their shares. A liquid market can be defined as a market where large transactions can be carried out without any effect on the prices of security (Dalv \& Baghi, 2014). Along with other variables like market size and market capitalization, market liquidity is often considered one of the best instruments to gauge the performance of the stock business.

Market liquidity promotes a variety of transactional properties of the market (Mockus, 2012). According to Tehrani, Ahmadinia, and Hasbaei (2011), liquidity can be characterized as the ability to make a transaction rapidly and with little or and no dramatic adverse effect on share prices and market depth. That is the ability to make transactions at current market prices.

Switzer and Picard (2016) paper use a nonlinear approach to capture the dynamics of macroeconomic time series to investigate the relationship between business cycles and market-wide liquidity. Applying both the Markov switching-regime and the autoregressive smooth-transition models and various liquidity proxies, this study provides insufficient evidence that the dynamics of liquidity serve as the leading indicator of potential economic conditions. Whether aggregate liquidity on the stock market can be used to forecast the future state of the economy remains an open question.

Ogunrinola and Motilewa (2015) research analyzed the effect of stock market liquidity between the years 1980 and 2012 on Nigeria's economic development. Using Eviews 5.0 econometric software, stationarity tests using the Augmented Dickey-Fuller method were performed while the normal least square (OLS) technique was used to estimate the basic model defined for the analysis. The findings of data analysis showed that variables were stationary at their first difference, while the Johansen cointegration method verified the presence of a cointegrating relationship at the level of 5 per cent. Surprisingly, the study found that stock market liquidity for the periods under review was not a statistically significant variable explaining Nigeria's economic growth.

According to Chipaumire and Ngirande (2014), a stock market is a financial institution that promotes the capital formation and allocation competence. It also helps governments and companies fund new ventures and develop and modernize commercial or industrial issues by increasing long-term capital. The paper analyzed the effect of the stock market on South Africa's economic development. The researchers used the Ordinary Least Square Regression (OLSR) along with Augmented Dickey-Fuller (ADF) for stationary research using time series data from 1995-2010. The paper argues that economic growth in South Africa affects the stock market liquidity

\subsubsection{Stock Market Capitalization}

Market capitalization has a significant impact on economic growth and development (Kuvshinov \& Zimmermann, 2019), and the position of this influence is growing. Indeed, over the last few decades, the capital market has had remarkable growth, and more businesses are turning to it to get new risk capital and diversify the overall risk. Also promoting the process is the internationalization of capital procurement markets and various developments in the negotiating methods, as well as the growing disintermediation of the banking system. A company's capitalization is the result of a share's price for the number of shares issued and listed. The number of capitalization of the companies listed on the market is equal to the value of the stock market's total capitalization.

Market capitalization is a significant market measure of equity ownership and overall business ownership (Onoh, Ibekwe, Onoh, \& Egbo, 2018). Several types of research indicate that the macroeconomic climate has a substantial influence on the pace of capitalization of the stock market (Riyanto \& Arifin, 2018). Therefore, the market share price represents both endogenous factors depending on the growth of the single issuing firm and 
exogenous factors or "scenario factors" relevant to the overall economic results.

The factors that influence the stock price index most are usually difficult to define. In recent decades, insightful studies have been carried out in particular on the relationship of the stock market with macroeconomic variables (Thamprasert, Pastpipatkul, \& Yamaka, 2018). These studies mostly focus on macroeconomic factors.

\subsection{Economic Growth}

Economic growth, as Riley (McClelland, 2019) explains, is a long-run expansion of the productive capacity of a nation. In other words, it means an improvement in an economy's capacity to generate products and services in relation to the country's successive developments, which are typically correlated with technological change. Economic growth has been expressed recently not only in terms of the capacity of the country to increase the productivity potential, such as capital stock and technological advancements but it also includes improvement in people's quality of life in that country, as well as improving the quality and literacy rates (Banerjee, Duflo, \& Qian, 2020).

Economic growth is an increase in the output of goods and services over a given period. To be more precise, the calculation of economic growth will exclude the inflationary impacts (Hsieh, Hurst, Jones, \& Klenow, 2019)). Economic growth creates more income for businesses (Bhat \& Laskar, 2016), leading to a rise in stock prices and capital, enabling companies to invest and recruit more employees. As more jobs are created, revenues increase. Consumers have more resources to buy additional goods and services. An increase in aggregate demand drives higher economic growth. It is for this reason that every country needs positive economic growth. This makes economic growth the economic variable most-watched for (Kim, Yu, \& Hassan, 2018).

There has been much research into the determinants that impact economic growth. Experts traditionally focused on factors that include capital, labor, and technological advancement as the elements that are germane to economic growth. However, current studies on economic growth have come out with a lot of new factors that influence the growth of the economy, such as social capital, innovation activities, macroeconomic environment, political stability, financial development instead of traditional factors: capital, labor, and technology (Chizea, 2012).

The easiest way to measure economic growth is through the Gross Domestic Product (GDP) (Kummu, Taka, \& Guillaume, 2018). It takes into consideration the total economic production of the country. This includes all the products and services manufactured by companies in a country (Hill, 2017) for sale whether domestically or overseas. According to Anghelach, Partachi, Sacalã, and Ursache (2016), final production is calculated by GDP. It does not include the parts which are made for producing a product. It also includes exports since the country manufactures them.

While economic prosperity restrains imports (Antolini, 2016) GDP however does not include services that are unpaid. This leaves out child care, unpaid charity work, or criminal activity on the black market. It does not count the costs to the community (Anghelache, Diaconu, Marinescu, \& Popovici, 2016). For instance, plastic prices are cheap because it does not include disposal costs. As a consequence, GDP does not measure how such costs affect society's well-being. A nation will raise its living conditions as it is factoring in environmental costs. A culture tests only that which it respects.

Analysts are monitoring economic growth to find out at which point of the business cycle the economy is (Bilan, Gavurova, Stanisław, \& Tkacova, 2017). The economic cycle is measured by the upward and downward movement of gross domestic product. The best step will be expansion. This is because sustainable fashion is the expansion of the economy. If growth goes too far above a sustainable rate of growth, it will overheat (Škare \& Stjepanović, 2016). It is the period of the peak or boom of the business cycle. Inflation sets in as too much money chasing few products and services, generating a bubble for the money as in the case with the housing market in 2005-2006.

According to Jordà, Schularick, and Taylor (2017), confidence in economic development dissipates somewhere, the economy contracts as more people sell than buy. This leads to a recession as the period of the economic cycle continues. One economic downturn is a decade-long recession (Duval, Li, Saraf, \& Seneviratne, 2016). The last time that occurred was during the 1929 Great Depression.

\subsection{Stock Market Development and Economic Growth}

Pan and Mishra (2018) argue that the interplay between the stock market and the real economy is crucial through the various channels financial markets drive economic growth. Their recent study examines the impact of this relationship on the world's fastest-growing and largest emerging market, the Chinese market. In addition to systemic breaks and the Autoregressive Distributed Lag (ARDL) model. The results showed that the 2007 to 
2012 global financial crisis had a huge impact on both China's real economy and the financial sector. The results also indicate that there has been a long-term negative correlation between the Shanghai A share market and the real economy sector; however, the extent of effect has been minuscule. Such results indicate that this negative relationship is indicative of the so-called nature of the excessive stock market boom and the economic bubble in China's financial sector. The results provided no proof at all of a short-term relationship between the stock market and the real economy. Toda Yamamoto's causality test showed that the development of the Shenzhen B share market had been spurred by economic growth. In addition, the similarly weighted index showed that stock market liquidity and sectoral indices of the stock market were alternative indicators of stock market activity. The findings have been reliable for alternative stock market activity tests. The findings also suggest that state-owned monopolies play a significant role in China's economic success because they drive the economy in the short term.

Kajurová and Rozmahel (2016) paper discusses the causal relationship between the performance of the financial markets and economic growth in the countries within the European Union. In particular, it explores the course of existence and causality. To show the existence and course of causality, panel data techniques were applied, including cointegration tests, Vector Error Correction models, and Granger Causality tests. The study of Euro area member countries observed long-run effects of economic growth on stock market development. Additionally, in that country-sample, the short-run mutual relationship between growth and stock markets was indicated. Only the short-run effect of stock market development on economic growth has been noticed in non-Euro area countries. The empirical findings have policy implications for macroeconomic stabilization and growth. The relationships indicated also play a part in forecasting economic growth and the performance of stock markets.

Ananwude and Osakwe (2017) research focused on camaraderie reconnaissance and analyzed the long-term relationship between the creation of the stock market and Nigerian economic growth from 1981 to 2015. Market capitalization ratio and the turnover ratio were used to calculate the depth of development of the stock market in Nigeria, while real gross domestic product growth rate represents economic growth. Secondary data were collected from the Nigerian Stock Exchange (NSE) and the Nigeria Bureau of Statistics (NBS). The data were analyzed using the Autoregressive Distributed Lag (ARDL) model. From the research completed, Nigeria's stock market scope of development has a constructive but negligible relationship with short-term and long-term economic growth. The study of granger causality dispelled Nigeria's stock market's ability to propel production. The stock market is growth-inducing, but economic growth is independent of stock market activity in the case of Nigeria. The study suggested to the government to steadfastly address inhibiting factors such as infrastructural inadequacy, poor institutional, and regulatory structure that encumbers the stock market from achieving its capital mobilization objective for economic growth.

Sehrawat and Giri (2017) study used quarterly time-series data from 2003:Q4 to 2014:Q4 to analyze the relationship between the Indian stock market and economic growth from a sectoral perspective. The findings of the boundary test of the Autoregressive Distributed Lag (ARDL) method support the presence of a cointegrating relationship between sector-specific GDP and sector-specific stock indices. The empirical findings show that sector-specific economic growth is significantly affected both in the long run and in the short run by shifts in the respective sector-specific stock price indices. In addition, the control variables, such as trade openness and inflation, act as the instrument variables in describing the fluctuations in the economy's sector-specific GDP. The findings of the Granger causality test show both long-run unidirectional and short-run causality running from sector-specific stock prices to the respective sector GDP. The results indicate that the country's economic growth is prone to investments in the respective sub sectoral stock market. The results underline the reasons for business cycles for the overall economy.

Mamun, Ali, Hoque, Mowla, and Basher (2018) looked at the last one and a half decades of Bangladesh's growth success along with stock market development, which has spurred the query of whether stock market development has a major effect on the country's economic growth. The study examines the time series proof of the effects of stock market development on the Bangladesh economic growth for the period 1993-2016, using ARDL Bounds testing approach and found that stock market development has a direct impact on economic growth, both in the short run and the long run, along with financial depth, interest rate spread and real effective exchange rate. Granger causality tests indicate a bidirectional causal link between the performance of the stock market and economic growth. The analysis, however, fails to define a convergent mechanism to equilibrium in terms of stock market growth along with other factors with major economic implications. Continuous increase in financial depth and decrease in interest rates spread across the sample period with consistent performance of real effective exchange rates except for some spikes in recent years boost the demand for all concerned to play the required role in confirming stock market stability and its growth in order to validate the stability of equilibrium in 
the long-run.

Ofori-Abebrese, Kamasa, and Pickson (2016) research used the ARDL model in conjunction with the Granger causality test to investigate the connection of stock market development and economic growth in Ghana for the 1991-2011 period. The study showed that stock market development has a negative long-run impact on economic growth, and this was supported by the causality test that there is no association between stock market development and economic growth in Ghana. Human capital and money supply made a positive contribution to growth. Inflation and foreign direct investment did not appear to be deterministic factors in economic development. The study concluded that Ghana Stock Exchange operators should strategize well to draw more Stock Exchange investors. Furthermore, the Bank of Ghana should adhere to the central bank's independence, further development of financial and money markets in order to facilitate the implementation of monetary policy to achieve price stability in the country.

Bayar, Kaya, and Yildirim (2014) noted that studies have increased the role of stock market innovations in economic growth in recent years. In the 1999-2013 analysis report, the Johansen-Juselius cointegration test and the Granger causality test were employed to examine the link between stock market development and economic growth in Turkey. The empirical findings show that there is a long-run relationship between economic growth and stock market capitalization, the total value of stocks traded, turnover ratio of stocks traded. Furthermore, there is a unidirectional causality running from stock market capitalization, the total value of stocks traded, and the turnover ratio of stocks traded to economic growth.

Naik and Padhi (2015) aim of this analysis is to analyze the effect of stock market development on economic growth for a panel of 27 emerging economies by annual data over the 1995-2012 period empirically. A second-generation panel root unit test developed by Pesaran (2007) was used to check the data series of stationary properties. The authors use a dynamic panel "machine GMM" estimator to attain the study goals and minimize the endogeneity problem that occurs in the given model. In addition, the authors use a heterogeneous panel causality test proposed by Dumitrescu and Hurlin (2012) to analyze the path of causality between variables. The empirical results show that the performance of the financial markets leads significantly to economic growth. Therefore, a unidirectional causality has been identified, running from the stock market improvement to economic growth. This result is consistent with the supply-lead hypothesis. The study, however, noted that other macroeconomic variables, such as trade openness, investment ratio, and exchange rates, have a substantial effect on economic growth, in addition to the performance of stock markets. The results also indicate that a more competitive stock market, a more globalized economy, and rising aggregate investment could theoretically encourage economic development for these emerging economies.

Owusu and Odhiambo (2014) article look at the relationship between the creation of the stock market and sustainable economic growth in Ghana. The study employed the recently established ARDL-bound testing method and multidimensional proxies for stock market growth to analyse this relation. The paper notes that stock market changes and capital account liberalization policies have no positive impact on Ghana's economic growth in the long term. This finding confirms the numerous past studies which have reported negative or inconclusive results on the economic growth effects of stock market creation. Therefore, the article concludes that the increase in credit to the private sector, rather than the growth of the stock market, drives the growth of the real sector in Ghana.

Jedidia, Boujelbène, and Helali (2014) paper looked at an empirical investigation into whether financial development in Tunisia would improve economic growth. They used an Autoregressive Distributed Lag approach to assess the financial-growth relationship by taking private credit, value traded, and issuing stock-market securities from banks as measures for stock market development. The empirical study showed that private-sector domestic credit positively impacts economic growth, indicating that financial stability is a catalyst for long-term economic growth, but is subject to short-term financial fragility. This study further confirmed the view of the bidirectional link between credit and economic growth. However, the study found that neither the development of the stock market nor the intervention of banks in the stock market had substantial and positive effects on economic growth. The study recommended that financial reforms of the Tunisian stock market be given priority in order to contribute to savings mobilization and long-term economic development.

Durusu-Çiftçi, Ispir, and Yetkiner (2017) research help to explain theoretically and empirically the role that financial development plays in economic growth. In the theoretical part of the paper, by employing a SolowSwan growth model enhanced with financial markets in the tradition of $\mathrm{Wu}$, Hou, and Cheng (2010), they evidenced that debt from credit markets and equity from stock markets are two long-run determinants of GDP per capita. In the empirical aspect, the long-run relationship is analyzed for a panel of 40 countries over the 
period 1989-2011, using Augmented Mean Group (AMG) and Common-Correlated Effects (CCE), both of which permit cross-sectional dependencies. Within fact, this is a long-term relationship. Although transverse results differ from country to country, panel research suggested that both channels have a long-term positive effect on the level of GDP per capita, the credit markets contribute significantly higher. In order to ensure that policies are enforced with the intention of strengthening the financial markets, the study proposed that policymakers concentrate in particular upon regulatory and legal initiatives to strengthen creditor and investors rights and contract compliance. The study concluded that economic growth would be stimulated by fostering the creation of the financial sector of a nation.

Peia and Roszbach, (2015) article explored the empirical relationship between economic growth and financial sector, while (i) taking their complexities into account and (ii) differentiating between capital market and the growth of the banking sector. For 22 advanced economies, they studied cointegration and linkage between finance and development. The time-series study showed that trends of causality are based on whether the growth of the real sector emanates from the stock market or from the banking industry. The study evidenced that the development of the stock markets appears to trigger economic growth, while there is a reverse causality between the development of the banking sector and the growth of the real sector. These findings indicate that there are likely to be different directions of the causal relationship between finance and growth at a high level of development.

There is widespread consensus that dynamic capital markets have an immense effect on countries' economic growth. This study by Ali (2015) examines the economic development of BRICS (Brazil, Russia, India, China, and South Africa) and Turkey. The study used market capitalization ratio, turnover ratio, and total value of shares traded as a percent of GDP as proxies to stock market development while GDP per capita and FDI as a percentage of GDP to establish the intricate relationship between stock market development and economic growth in these countries.

The VAR results revealed major positive ties, showing that the growth of the stock exchanges in Russia, India, and China has an important and positive effect on economic development. The Granger Causality Primary Test shows that the growth in stocks affects economic growth considerably and robustly for Russia, India, Turkey, and South Africa, while Brazil and China are noting that economic growth fosters stock market development by way of liquidity enhancements. The results cannot be generalized due to the complex nature of the relationship between financial markets and economic development. Therefore, more work is required to obtain more proof of their interaction.

In a research by Sibanda and Holden (2015) based on the Southern African Development Community (SADC), Member States have seen a varying degree of economic growth and stock market development, with foreign investors concentrating on emerging market economies for real growth. The only nation of the 15-Member States with an established and stable stock market is South Africa with a gross domestic product (GDP) worth US\$ 481.1 billion. Seven selected SADC economies are included in the study using the Granger Causality approach and the Vector Error Correction Model to evaluate the relationship between the countries' economic growth and stock market development. The study draws a conclusion on the theory of demand pulling between economic growth and stock market development suggested by Patrick (1966), particularly regarding the selected SADC states.

The Nwaolisa and Chijindu (2016) study examines the causality between the depth of capital market development and economic growth in Nigeria and the short-term and long-term capital market dynamics. Yearly gross domestic product growth rates from 1981 to 2015 at current market prices, stock market capitalization and value of stock traded ratio to GDP were used for the analysis. The data on the various issues were collected from the Nigerian Stock Exchange and the Nigerian Bureau of Statistics. The diagnostic test, such as heteroscedasticity, normality, and multicollinearity, were carried out prior to the estimation. The results of Phillips Perron (PP) and Augmented Dickey-Fuller (ADF) research showed the convergence of variables in order one.

The Granger Causality Test findings indicate that there is no causal linkage between the death of stock market development in Nigeria and economic growth at 5 per cent significance level. The cointegration test of Johansen showed that there is a long-term relationship between the depth of development of Nigerian stock market, measured by market capitalization and value of stock traded ratio to GDP, and economic growth represented by GDP growth rate at 5 per cent level of significance. The results of the error correction model show that when the Growth Rate of the GDP and Capitalization Ratio (or stock market ratio value) move away from the long-term equilibrium, then GDP Growth Rate adjusts to restore the long-term equilibrium by correcting the imbalance by 
about 1.25 (or 1.21). The study shows that a long-term relationship exists between the depth of development of Nigeria's stock market and economic development. The depth of development in Nigeria stock market, however, does not spur economic growth, nor does economic growth boost the depth of development of the Nigerian stock market. This study contributes to the empirical literature on the significant long-term causality between stock market development and economic growth in Nigeria.

Lazarov, Miteva-Kacarski, and Nikoloski (2016) had two purposes in this article. The first objective is to investigate the impact of stock market development on the economic growth of the 14 emerging economies from the Central and South-East European (CSEE) regions in the period 2002 to 2012 and the second is to evaluate the key features and dynamics of the stock market in the Republic of Macedonia. To realize the first objective, panel regression models (fixed and random effects) and a dynamic panel model (Generalized Method of Moments - GMM) were applied. In the case of the second objective, a single country approach and comparative analysis were employed to examine the dynamics of the Macedonian stock market. The findings suggest that the performance of the stock market is optimistic and strongly correlated with economic growth. Furthermore, the comparative capital market study reveals that the Macedonia stock market is still underdeveloped and confronted with plenitude of obstacles as a result of the negative effect of the global financial crisis, which has to be overcome before the market can begin new growth. The issues facing the Macedonian stock market included the integration of the regional stock markets, harmonization of the legal and administrative systems such as bankruptcy, accounting and reporting requirements, regulatory bodies for the public sector, corporate governance, and trade liberalization environment.

Nabieu and Barnor (2016) carried out a research employing time series data from 2000 to 2012 to explore the impact of stock market performance on economic growth in Ghana. Quarterly data were collected on all variables for the thirteen year period (2000 to 2012). With the use of Granger Causality and the Vector Error Correction Model (VECM) tests, the research examined the short-term and long-term relationships between stock market performance and economic development in Ghana. The study found that stock market success in the short and long term positively impacted economic development. The causality test of bond market development on the performance of the Ghanaian economy showed a bidirectional relationship between the two variables, meaning that there is an interdependence linkage between capital market development and economic growth.

Therefore, the stock market promotes the growth of the economy, and economic growth stimulates the development of stock market activities. The study concludes that policies aimed at the growing stock market should be improved to spur economic growth.

Kadenge and Tafirei (2014) paper using the annual 1988-2012 data explores the short-term and long-term impact of banking and stock market development on economic growth in Zimbabwe. To analyze short-term and long-term relationships simultaneously, Auto-Regressive Distributed Lag (ARDL) method and the Vector Error Correction mechanism were employed with a more financially enhanced economic growth function. In order to calculate trends in the banking sector and the stock market, bank and stock market trends, indices are used. The results show that economic growth, banking sector, and stock market developments have a long-lasting relationship. Banks have a greater effect than stock markets on economic development. This supports the supply leading hypothesis. Results show that the banking system encourages economic development better than the stock market based on a financially-driven framework.

\subsection{Theoretical Framework}

The theories supporting economic growth in this study are the Malthusian theory, classical growth theory, and solow-swan model.

\subsubsection{The Malthusian Theory}

The theory of Malthus indicates that technological developments in most human history resulted in greater population growth but do not, in the long run, have an impact on per capita income. According to this theory, while technologically advanced economies were characterized by a higher population during the pre-industrial period, their per capita income was not distinct from those of technologically regressed societies. Thomas Malthus was the philosophical foundation of the Malthusian theory.

\subsubsection{Classical Growth Theory}

In classical (Ricardian) economics, production theory and growth theory rely on the principle or rule of variable-level proportion, whereby the growth of any production factor (labor or capital) will increase output while retaining the other factor constant and without making any technological adjustments, the marginal 
product of labour or capital will diminish and eventually close to zero. Such ideas come from the theory of agriculture by Thomas Malthus. Examples of Malthus include the number of seeds harvested compared to the number of seeds planted on a plot and the size of the crop from a land compared with the number of workers working.

The classical economic growth theory has been criticized for continuously retaining technology, a significant factor in economic growth, and ignoring economies of scale. One of the most common theories in the 1940s was a massive pushing model that proposed that countries had to save from one development to another through a virtuous cycle of massive investment in infrastructure and in education. Kevin Murphy, Andrei Shleifer, and Robert Vishny resurrected and rigorously developed the theory in the late 80s.

\subsubsection{Solow-Swan Model}

Robert Solow and Trevor Swan established the ultimate model for economic growth in the1950s. This model assumes that continuous investment in capital and labor stimulates the rate of economic growth but only in the short term owing to diminishing returns. As the marginal output of additional units of capital declines, the economy adjusts itself to a long-term growth path. A 'steady-state growth path' is reached when output, capital, and labor are all growing at the same rate, so output per worker and capital per worker are constant. When the steady growth state is achieved and the nation's resources are fully employed, the economy's rate of growth can only be improved through innovation and technological changes. The Solow-Swan model argues that the gap between developed and developing countries will close, a situation called the catch-up growth. This is because the emerging economies have not made much capital investment, so further capital investment will yield a higher return than in developed economies which have reached their steady-state growth paths.

The Solow-Swan model is considered an exogenous model of growth because it does not justify why countries spend different levels of capital as a percent of gross domestic product and how to enhance the level of technological advancement.

The benefit of the model lies in its contribution to growth theory. It demonstrates the stability of steady-state growth. Long-run economic growth is achieved through increase in labor force and technological advancement.

Some of the drawbacks of the model are that: (i) the model ignores the study of technological advancement. Technology is considered only as an exogenous variable in the process, (ii) the model hypotheses that capital is homogeneous. But capital goods are heterogeneous, and this variation may create difficulty in obtaining the path of steady growth.

\subsection{Conceptual Framework}

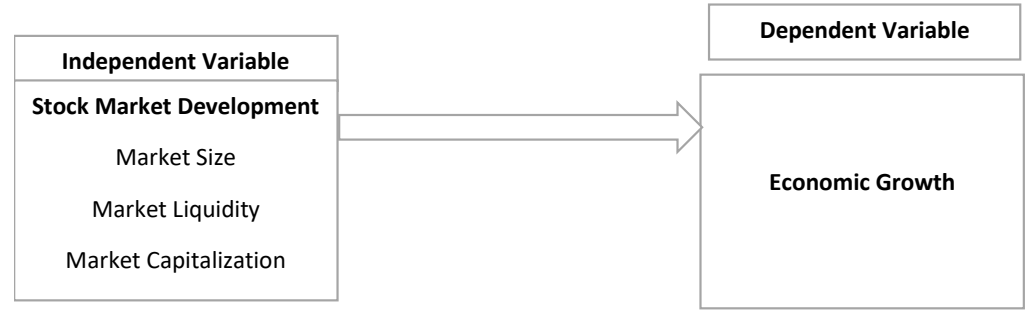

Figure 1. Explaining the relationship between stock market development and economic growth

\subsection{Definition of Terms}

Economic Growth: It is a long-run expansion of the productive capacity of a nation.

Stock Market Development: This is typically calculated by stock market size, liquidity, volatility, concentration, alignment with global capital markets, and the market legal law, regulation, and supervision.

Stock Market Capitalization: The total monetary market value of all listed firms outstanding shares traded.

Stock Market Liquidity: The market liquidity indicator is equivalent to the total value of domestic share transactions that are divided by the total market value of all listed firms outstanding shares traded/market capitalization.

Stock Market Size: The size of the market is based on the market capitalization ratio of listed companies that are divided by the gross domestic product.

\section{Methodology}

This session discusses the research design, populations, sampling technique, instrumentation, and data analysis. 


\subsection{Research Design}

The research design is a correlational study. It looks for the causal relationship between stock market development and economic growth in Ghana. A correlational analysis is a form of research design in which a researcher attempts to understand what relationship exists between two or more variables. Correlative work attempts, in simple terms, to decide whether and if so, in which way two or more variables are associated (Curtis, Comiskey, \& Dempsey, 2016; Asamoah, 2014).

\subsection{Population and Sampling Technique}

The study used secondary data obtained from the Ghana Statistical Service (GSS) and Ghana Stock Exchange (GSE). The annual data were collected for five years (2014 to 2018). Gross Domestic Product (GDP) values in real terms and growth rates were collected from the GSS. Total stock market capitalization and total value traded of thirty-one firms and two corporate bonds listed on the GSE were obtained. Additionally, the data acquired were used to compute the stock market size and stock market liquidity. The stock market size was computed by dividing total market capitalization by real GDP value, whereas stock market liquidity was calculated by dividing total value traded by market capitalization.

\subsection{Instrumentation}

Secondary data from 2014 to 2018 obtained from the GSS and the GSE were used. In determining the direction, magnitude, and given verbal interpretation, the study used Cohen's (1988) approach. The magnitude of the relationship strength is calculated and represented on the Cohen (1988) absolute values, where $\mathrm{r}=.10$ to .29 is small/low, $\mathrm{r}=.30$ to. 49 is medium / moderate, and $\mathrm{r}=.50$ to 1.0 is large / high. Also, the study determined the statistical significance level at 5 per cent.

\subsection{Analysis of the Data}

As a correlational study, the research questions one to three were analyzed with the use of bivariate regression, while multiple regression was used in analyzing question four. According to Denis (2018), bivariate correlation and regression assess the degree to which two quantitative variables relate. The Pearson correlation coefficient (r), the most widely used technique for bivariate correlation, calculates the relationship of two quantitative variables without distinction between the independent and dependent variables. Bivariate regression uses the relationship between the independent and the dependent variables to estimate the independent variable score.

Multiple regression describes the most suitable set of dependent variable predictors or independent variables (Cronk, 2019). This is often used where multiple independent quantitative variables and one quantitative dependent variable occur. A multiple serial regression chooses independent variables, one at a time, by their ability to compensate for the variation in the dependent variable, in order to achieve the best combination of dependent variable predictors

\section{Results and Discussion}

This session discusses the analysis, critical discussion, and interpretation, as provided by the literature. Results were extracted from quantitative data and interpreted accordingly. The study answered all the study questions raised in Chapter one.

\subsection{Correlate of Market Liquidity and Economic Growth}

Research question one examines the significant relationship between stock market liquidity and economic growth. The results, as shown in Table 1, indicate that there is a high positive relationship between market liquidity and economic growth but not statistically significant $(\mathrm{r}=.839, \mathrm{p}=.076)$. This means that for economic growth to increase, market liquidity on the GSE must also increase. In other words, stock market liquidity influences economic growth in Ghana. This is because they are positively correlated. Therefore, the study failed to reject the null hypothesis that there is no significant relationship between market liquidity and economic growth.

Table 1. Correlate of market liquidity and economic growth

\begin{tabular}{lll}
\hline Correlations & & \\
\hline & & Real GDP Growth \\
\hline Market Liquidity & Pearson Correlation & .839 \\
& Sig.(2-tailed) & .076 \\
& $\mathrm{~N}$ & 5 \\
\hline
\end{tabular}


The findings from this study are supported in the literature by Kumar and Misra's (2015) argument that market liquidity is germane to stock market development. Most successful investments are long-term and require long-term capital commitment. Savers are risk-averse and unable to relinquish control of their savings capital for longer periods; equity markets should draw more investors because they offer assets that can be sold to savers easily and economically.

A liquid market enables savers to invest in long-run projects and also helps them to access their capital quickly before the project is finished and the profits are dispersed (Fidrmuc, Fungáčová, \& Weill, 2015). That can be done easily by selling their stock market claims. This means the more competitive the stock market, the lower the barriers to investing in long-run ventures. Liquidity on the stock exchange can also raise savings returns, provided the viability, and probably cheaper funding for further investment projects.

\subsection{Correlate of Market Size and Economic Growth}

The second question investigated the significant relationship between stock market size and economic growth. The result from the study showed a moderate negative association between market size and economic growth but not statistically significant $(\mathrm{r}=-.355, \mathrm{p}=.558)$, as shown in Table 2 . This implies that there is an inverse relationship between market size and economic growth. As the market size increases, economic growth also decreases due to the tax charge on the stock exchange transactions. The study failed to reject the null hypothesis, which stated that there is no significant relationship between market size and economic growth.

Table 2. Correlate of market size and economic growth

\begin{tabular}{lll}
\hline Correlations & & \\
\hline & & Real GDP Growth \\
\hline Market Size & Pearson Correlation & -.355 \\
& Sig.(2-tailed) & .558 \\
& $\mathrm{~N}$ & 5 \\
\hline
\end{tabular}

The findings of this study are supported by the assertion that though large markets do not always work efficiently, taxes may distort incentives for listing on the exchange (Shahbaz, Shahzad, Ahmad, \& Alam, 2016). Their assessment focuses only on market size and does not take into account other elements of growth.

Again Ofori-Abebrese, Kamasa, and Pickson (2016) research used the ARDL model in conjunction with the Granger Causality test to investigate the connection of stock market development and economic growth in Ghana for the 1991-2011 period. The study showed that stock market development has a negative impact on the long term economic growth, and this was supported by the causality test that there is no association between stock market development and economic growth in Ghana

\subsection{Correlate of Market Capitalization and Economic Growth}

Question three scrutinized the relationship between market capitalization and economic growth. As indicated in Table 3, there is a moderately positive relationship between market capitalization and economic growth but not statistically significant $(\mathrm{r}=.423, \mathrm{p}=.478)$. This means that as the market capitalization of the GSE increases, it has a direct impact on economic growth; however, this is not backed by statistical data present. Therefore, the paper failed to reject the null hypothesis, which stated that there is no significant relationship between market capitalization and the economic growth of Ghana.

Table 3. Correlate of market capitalization and economic growth

\begin{tabular}{lll}
\hline Correlations & & \\
\hline \multirow{3}{*}{ Market capitalization } & & Real GDP Growth \\
& Pearson Correlation & .423 \\
& Sig.(2-tailed) & .478 \\
\hline
\end{tabular}

These findings are supported by the study of (Onoh, Ibekwe, Onoh, \& Egbo, 2018), which noted that market capitalization is a significant market measure of equity ownership and overall business ownership. Many types of research indicate that the macroeconomic climate has a substantial influence on the pace of capitalization of the stock market (Riyanto \& Arifin, 2018). 


\subsection{Predictors of Economic Growth}

The fourth question looked at the predictors of economic growth based on the three dimensions of stock market development indicators employed by this study. As shown in Table 4, the stock market developments indicators which are made of Market Liquidity (ML), Market Size (MS) and Market Capitalization (MC) account for 95.7 per cent of economic growth in Ghana from the year 2014 to 2018, meaning that stock market development association to economic growth is high and positive, but not statistically significant $\left(\mathrm{r}=.978, \mathrm{r}^{2}=.957, \mathrm{~F}=\right.$ $7.458, \mathrm{p}=.261$ ). This study confirms that market liquidity, size, and capitalization are all predictors of economic growth. However, there are 4.3 per cent of other factors or variables which were not included in this study.

These results are confirmed by Naik and Padhi (2015) study, which provided empirical results showing that the performance of the financial markets leads significantly to economic growth. Their findings identified a unidirectional causality running from stock market performance to economic growth. The result was consistent with the supply-leading hypothesis. It is also obvious that macroeconomic variables, such as trade openness, investments, and exchange rates, have a substantial effect on economic growth, in addition to the performance of stock markets. The results further indicate that a more competitive stock market, a more globalized economy, and rising aggregate investment could theoretically encourage economic development for emerging economies.

Table 4. Predictors of economic growth

\begin{tabular}{|c|c|c|c|c|c|c|c|c|c|c|}
\hline \multicolumn{11}{|c|}{ Model Summary } \\
\hline \multirow[b]{2}{*}{ Model } & \multirow[b]{2}{*}{$\mathrm{R}$} & \multirow[b]{2}{*}{ R Square } & \multirow[b]{2}{*}{ Adjusted R Square } & \multirow[b]{2}{*}{ Std. Error of the Estimate } & \multicolumn{6}{|c|}{ Change Statistics } \\
\hline & & & & & R Square Change & F Change & df1 & $\mathrm{df} 2$ & Sig & Change \\
\hline 1 & $.978^{\mathrm{a}}$ & .957 & .829 & 1.0674 & .957 & 7.458 & 3 & 1 & & 61 \\
\hline \multicolumn{11}{|c|}{ a. Predictors: (Constant), Market Liquidity, Market Size, Market Capitalization } \\
\hline \multicolumn{4}{|l|}{ Model } & & n of Squares & Mean & Square & & $\mathrm{F}$ & Sig. \\
\hline \multirow[t]{3}{*}{1} & & & & Regression & 25.494 & 8.4 & 98 & & .458 & $.261^{\mathrm{b}}$ \\
\hline & & & & Residual & 1.139 & 1.1 & 39 & & & \\
\hline & & & & Total & 26.633 & 4 & & & & \\
\hline
\end{tabular}

a. Dependent Variable: Real GDP Growth.

b. Predictors: (Constant), Market Liquidity, Market Size, Market Capitalization.

Table 5. Coefficient

\begin{tabular}{|c|c|c|c|c|c|c|}
\hline \multicolumn{7}{|c|}{ Coefficients $^{\mathrm{a}}$} \\
\hline \multirow[b]{2}{*}{ Model } & & \multicolumn{2}{|c|}{ Unstandardized Coefficients } & \multirow{2}{*}{$\begin{array}{c}\text { Standardized Coefficients } \\
\text { Beta } \\
\end{array}$} & \multirow[b]{2}{*}{$\mathrm{T}$} & \multirow[b]{2}{*}{ Sig. } \\
\hline & & $\mathrm{B}$ & Std. Error & & & \\
\hline \multirow[t]{4}{*}{1} & (Constant) & -16.032 & 9.367 & & -1.711 & .337 \\
\hline & Market Capitalization & .002 & .001 & 3.408 & 2.413 & .250 \\
\hline & Market Size & -180.160 & 74.081 & -3.206 & -2.432 & .248 \\
\hline & Market Liquidity & -1796.842 & 1078.188 & -1.933 & -1.667 & .344 \\
\hline
\end{tabular}

a. Dependent Variable: Real GDP Growth

In order to determine the mathematical model for this study, a regression analysis was done. Based on the unstandardized coefficient the equations for Economic Growth is: Real GDP Growth $=-16.032+0.002 \mathrm{MC}$ $-180.160 \mathrm{MS}-1796.842 \mathrm{ML}+\mathcal{E}$ as shown in Table 5. These results show a mixed impact on the stock market development should the economy have to grow by $1 \%$. Whereas Market Capitalization increases, both Market Liquidity and Market Size will decrease.

This mixed result is supported by Owusu and Odhiambo (2014) article, which looks at the relationship between the creation of the stock market and sustainable economic growth in Ghana. The study employed the recently established ARDL-bound testing method and multidimensional proxies for stock market growth to analyse this relation. The paper noted that stock market development and capital account liberalization policies have no positive impact on Ghana's economic growth in the long term. Their study confirmed the numerous past studies which have reported negative or inconclusive results on the effects of stock market creation on economic growth. Therefore, the article concluded that it is the increase in credit to the private sector, rather than the growth of the stock market, which drives the growth of the real sector in Ghana. 


\section{Summary, Conclusion, and Recommendations}

This chapter summarizes the results, conclusions, and recommendations from the study of the correlation between stock market development and economic growth in Ghana.

\subsection{Summary}

Based on the objectives set for this research, the following are the summarized findings:

The study has shown that there is a non-significant high positive relationship between market liquidity and economic growth. There is a moderate negative association between market size and economic growth but not statistically significant. Also, a moderately positive relationship between market capitalization and economic growth but not statistically significant. Finally, the predictors of economic growth based on stock market development indicators of market liquidity, size, and capitalization account for 95.7 per cent of economic growth in Ghana.

\subsection{Conclusion}

This study concludes that there is a mixed relationship between stock market developments on economic growth in Ghana. However, this association is not statistically significant. This confirms the causality of relationship findings in various studies discussed empirically in the literature review.

\subsection{Recommendation}

Based on the findings, the research makes the following recommendations;

1) Market Liquidity is a factor for economic growth in Ghana. Therefore, the Ghana Stock Exchange should continue to implement legal and financial reforms to enhance the market activities to improve the liquidity position of the market.

2) Market Size has shown that there is an inverse relationship between it and economic growth due to the small ratio of market capitalization to Gross Domestic Product. It is recommended that more firms should be listed on the stock market.

3) Market capitalization has a direct relationship with economic growth. Therefore, the GSE must encourage more firms to list on the exchange. There should be deliberate Government policy to offload part of the government's shareholdings in the state-owned enterprises on the GSE. Foreign companies in Ghana should also be incentivized through appropriate policies and legislation to make a list of the GSE.

4) The study recommends that future researchers should investigate the other determinants of economic growth that were not used in this study and do similar correlational studies.

\section{References}

Adu, G., Marbuah, G., \& Mensah, J. (2013). Financial evelopment and economic growth in Ghana: Does the measure of financial development matter? Review of Development Finance, 3(2013), 192-203. https://doi.org/10.1016/j.rdf.2013.11.001

Adusei, M. (2014). Does stock market development promote economic growth in Ghana. International Journal of Economics and Finance, 6(6), 119-126. https://doi.org/10.5539/ijef.v6n6p119

Ali, A. S. (2015). Stock market development and economic growth: An empirical analysis between Turkey and BRICS countries. In Chaos, Complexity and Leadership 2013 (pp. 269-283). Springer, Cham. https://doi.org/10.1007/978-3-319-09710-7_24

Al-Malkawi, H. A. N., Marashdeh, H. A., \& Abdullah, N. (2012). Financial development and economic growth in the UAE: Empirical assessment using ARDL approach to cointegration. International Journal of Economics and Finance, 4(5), 105. https://doi.org/10.5539/ijef.v4n5p105

Ananwude, A. C., \& Osakwe, C. I. (2017). Stock market development and economic growth in Nigeria: A camaraderie reconnaissance. Research Journal of Economics, 1(3), 1-6.

Anghelach, C., Partachi, I., Sacalã, C., \& Ursache, A. (2016). Using econometric models in the analysis of the correlation between the evolution of the Gross Domestic Product and Foreign Direct Investments. Romanian Statistical Review Supplement, 64(10), 124-129.

Anghelache, C., Diaconu, A., Marinescu, A. I., \& Popovici, M. (2016). Comparative study of the evolution of the Gross Domestic Product indicator. Romanian Statistical Review Supplement, 64(12), 165-172.

Antolini, F. (2016). The evolution of national accounting and new statistical information: Happiness and gross 
domestic product, can we measure it? Social Indicators Research, 129(3), 1075-1092. https://doi.org/10.1007/s11205-015-1156-6

Asamoah, M. K. (2014). Re-examination of the limitations associated with correlational research. Journal of Educational Research and Reviews, 2(4), 45-52.

Ayunku, P. E., \& Etale, L. M. (2015). Determinants of Stock Market Development in Nigeria: A Cointegration Approach. Advances in Research, 366-373. https://doi.org/10.9734/AIR/2015/12912

Banerjee, A., Duflo, E., \& Qian, N. (2020). On the road: Access to transportation infrastructure and economic growth in China. Journal of Development Economics, 102442. https://doi.org/10.1016/j.jdeveco.2020.102442

Bayar, Y., Kaya, A., \& Yildirim, M. (2014). Effects of stock market development on economic growth: Evidence from Turkey. International Journal of Financial Research, 5(1), 93. https://doi.org/10.5430/ijfr.v5n1p93

Bhat, S. A., \& Laskar, M. R. (2016). Interest rate, inflation rate, and gross domestic product of India. International Journal of Technical Research \& Science, 1(9), 284-288.

Bilan, Y., Gavurova, B., Stanisław, G., \& Tkacova, A. (2017). The Composite Coincident Indicator (CCI) for Business Cycles. Acta Polytechnica Hungarica, 14(7), 71-90. https://doi.org/10.12700/APH.14.7.2017.7.5

Chatterjee, U. K. (2015). Bank liquidity creation and asset market liquidity. Journal of Financial Stability, 18, 139-153. https://doi.org/10.1016/j.jfs.2015.03.006

Chipaumire, G., \& Ngirande, H. (2014). How stock market liquidity impact economic growth in South Africa. Journal of Economics, 5(2), 185-192. https://doi.org/10.1080/09765239.2014.11884995

Chizea, J. (2012). Stock Market Development and Economic Growth in Nigeria: A Time Series Study for the period 1980-2007. Retrived from http://www.nrl.northumbria.ac.uk/10337/1/chizea.john_phd.pdf

Chordia, T., Subrahmanyam, A., \& Tong, Q. (2014). Have capital market anomalies attenuated in the recent era of high liquidity and trading activity? Journal of Accounting and Economics, 58(1), 41-58. https://doi.org/10.1016/j.jacceco.2014.06.001

Cronk, B. C. (2019). How to use SPSS®: A step-by-step guide to analysis and interpretation. Routledge. https://doi.org/10.4324/9780429340321

Curtis, E. A., Comiskey, C., \& Dempsey, O. (2016). Importance and use of correlational research. Nurse Researcher, 23(6). https://doi.org/10.7748/nr.2016.e1382

Dalvi, M. R., \& Baghi, E. (2014). Evaluate the relationship between company performance and stock market liquidity. International Journal of Academic Research in Accounting, Finance and Management Sciences, 4(1), 136-144. https://doi.org/10.6007/IJARAFMS/v4-i1/550

Denis, D. J. (2018). SPSS data analysis for univariate, bivariate, and multivariate statistics. John Wiley \& Sons. https://doi.org/10.1002/9781119465775

Dike, C. (2016). Stock Market Efficiency Promotes Economic Development: Empirical Evidence from Africa. International Journal of Economics and Financial Issues, Econjournals, 6(3), 1287-1298.

Durusu-Ciftci, D., Ispir, M. S., \& Yetkiner, H. (2017). Financial development and economic growth: Some theory and more evidence. Journal of Policy Modeling, 39(2), 290-306. https://doi.org/10.1016/j.jpolmod.2016.08.001

Duval, R., Li, N., Saraf, R., \& Seneviratne, D. (2016). Value-added trade and business cycle synchronization. Journal of International Economics, 99, 251-262. https://doi.org/10.1016/j.jinteco.2015.11.001

Erdogan, O., Bennett, P., \& Ozyildirim, C. (2015). Recession prediction using yield curve and stock market liquidity deviation measures. Review of Finance, 19(1), 407-422. https://doi.org/10.1093/rof/rft060

Fidrmuc, J., Fungáčová, Z., \& Weill, L. (2015). Does bank liquidity creation contribute to economic growth? Evidence from Russia. Open Economies Review, 26(3), 479-496. https://doi.org/10.1007/s11079-015-9352-1

Guillén, M. F., \& Capron, L. (2016). State capacity, minority shareholder protections, and stock market $\begin{array}{llll}\text { development. } \quad \text { Administrative } & \text { Science }\end{array}$ https://doi.org/10.1177/0001839215601459

Hill, T. (2017). Manufacturing strategy: The strategic management of the manufacturing function. Macmillan 
International Higher Education.

Ho, S. Y., \& Iyke, B. N. (2017). Determinants of stock market development: a review of the literature. Studies in Economics and Finance. https://doi.org/10.1108/SEF-05-2016-0111

Hsieh, C. T., Hurst, E., Jones, C. I., \& Klenow, P. J. (2019). The allocation of talent and US economic growth. Econometrica, 87(5), 1439-1474. https://doi.org/10.3982/ECTA11427

Jedidia, K. B., Boujelbène, T., \& Helali, K. (2014). Financial development and economic growth: New evidence from Tunisia. Journal of Policy Modeling, 36(5), 883-898. https://doi.org/10.1016/j.jpolmod.2014.08.002

Jordà, Ò., Schularick, M., \& Taylor, A. M. (2017). Macrofinancial history and the new business cycle facts. NBER macroeconomics annual, 31(1), 213-263. https://doi.org/10.1086/690241

Kadenge, P. G., \& Tafirei, F. (2014). The impact of bank and stock market developments on economic growth in Zimbabwe: 1988 To 2012. Botswana Journal of Economics, 12(2), 74-94.

Kajurová, V., \& Rozmahel, P. (2016). Stock market development and economic growth: Evidence from the European Union. Acta Universitatis Agriculturae et Silviculturae Mendelianae Brunensis, 64(6), 1927-1936. https://doi.org/10.11118/actaun201664061927

Kim, D. W., Yu, J. S., \& Hassan, M. K. (2018). Financial inclusion and economic growth in OIC countries. Research in International Business and Finance, 43, 1-14. https://doi.org/10.1016/j.ribaf.2017.07.178

Kumar, G., \& Misra, A. K. (2015). Closer view at the stock market liquidity: A literature review. Asian Journal of Finance and Accounting, 7(2), 35-57. https://doi.org/10.5296/ajfa.v7i2.8136

Kummu, M., Taka, M., \& Guillaume, J. H. (2018). Gridded global datasets for gross domestic product and Human Development Index over 1990-2015. Scientific Data, 5, 180004. https://doi.org/10.1038/sdata.2018.4

Kuvshinov, D., \& Zimmermann, K. (2019). The big bang: Stock market capitalization in the long run. https://doi.org/10.2139/ssrn.3236076

Lazarov, D., Miteva-Kacarski, E., \& Nikoloski, K. (2016). An empirical analysis of stock market development and economic growth: the case of Macedonia. South East European Journal of Economics and Business, 11(2), 71-81. https://doi.org/10.1515/jeb-2016-0012

Mamun, A., Ali, M. H., Hoque, N., Mowla, M. M., \& Basher, S. (2018). The causality between stock market development and economic growth: Econometric evidence from Bangladesh. International Journal of Economics and Finance, 10(5), 212. https://doi.org/10.5539/ijef.v10n5p212

McClelland, D. C. (2019). The achievement motive in economic growth. In The Gap Between Rich And Poor (pp. 53-69). Routledge. https://doi.org/10.4324/9780429311208-6

Mockus J. (2012). On simulation of the Nash equilibrium in the stock exchange contest. Informatica, 23(1), 77-104. https://doi.org/10.15388/Informatica.2012.350

Nabieu, G. A., \& Barnor, C. (2016). The effect of stock market performance on economic growth in Ghana. International Journal of Financial Economics, 5(1), 12-32.

Naik, P. K., \& Padhi, P. (2015). On the linkage between stock market development and economic growth in emerging market economies: Dynamic panel evidence. Review of Accounting and Finance, 14(4), 363-381. https://doi.org/10.1108/RAF-09-2014-0105

Ngare, E., Nyamongo, E. M., \& Misati, R. N. (2014). Stock market development and economic growth in Africa. Journal of Economics and Business, 74, 24-39. https://doi.org/10.1016/j.jeconbus.2014.03.002

Nwaolisa, E. F., \& Chijindu, A. A. (2016). The Linkage between the Depth of Development In Nigerian Stock Market and Economic Growth: A Johansen Co-Integration Approach (1981-2015). Frontiers of Accounting and Finance, 1(1).

Nyasha, S., \& Odhiambo, N. (2015). Economic growth and market-based financial systems: A review. Studies in Economics and Finance, 32, 235-255. https://doi.org/10.1108/SEF-03-2014-0053

Nyasha, S., \& Odhiambo, N. M. (2017). Bank versus stock market development in Brazil: An ARDL bounds testing approach. South East European Journal of Economics and Business, 12(1), 7-21. https://doi.org/10.1515/jeb-2017-0001

Ofori-Abebrese, G., Kamasa, K., \& Pickson, R. B. (2016). Investigating the Nexus between Stock Exchange and 
Economic Growth in Ghana.

Ogunrinola, I. I., \& Motilewa, D. B. (2015). Stock market liquidity and economic growth in Nigeria (1980 to 2012). Journal of Economics and International Business Management, 3(6).

Ojo, A. T., \& Ayadi, O. F. (2014). Financial malpractices and stock market development in Nigeria. Journal of Financial Crime.

Onoh, J. O., Ibekwe, F. C., Onoh, U. A., \& Egbo, B. U. (2018). Measuring daily stock market returns using market capitalization ratio in Nigeria. GOUNI Journal of Management and Social Sciences, 4(2), 188-203.

Owiredu, A., Oppong, M., \& Asomaning, S. A. (2016). Macroeconomic determinants of stock market development in Ghana. International Finance and Banking, 3(2), 33-48. https://doi.org/10.5296/ifb.v3i2.9555

Owusu, E. L., \& Odhiambo, N. M. (2014). Stock market development and economic growth in Ghana: An ARDL-bounds testing approach. Applied Economics Letters, 21(4), 229-234. https://doi.org/10.1080/13504851.2013.844315

Pan, L., \& Mishra, V. (2018). Stock market development and economic growth: Empirical evidence from China. Economic Modelling, 68, 661-673. https://doi.org/10.1016/j.econmod.2017.07.005

Peia, O., \& Roszbach, K. (2015). Finance and growth: time series evidence on causality. Journal of Financial Stability, 19, 105-118. https://doi.org/10.1016/j.jfs.2014.11.005

Riyanto, A., \& Arifin, Z. (2018). Pump-Dump Manipulation Analysis: The Influence of Market Capitalization and Its Impact on Stock Price Volatility at Indonesia Stock Exchange. Review of Integrative Business and Economics Research, 7, 129-142.

Sehrawat, M., \& Giri, A. K. (2017). A sectoral analysis of the role of stock market development on economic growth: empirical evidence from Indian economy. Global Business Review, 18(4), 911-923. https://doi.org/10.1177/0972150917692242

Shahbaz, M., Shahzad, S. J. H., Ahmad, N., \& Alam, S. (2016). Financial development and environmental quality: the way forward. Energy Policy, 98, 353-364. https://doi.org/10.1016/j.enpol.2016.09.002

Sibanda, M., \& Holden, M. (2015). Stock market development and economic growth in the SADC region: Evidence from seven selected countries. PULA: Botswana Journal of African Studies, 27(2), 292-307.

Škare, M., \& Stjepanović, S. (2016). Measuring business cycles: a review. Contemporary Economics, 10(1), 83-94. https://doi.org/10.5709/ce.1897-9254.200

Soderbery, A. (2014). Market size, structure, and access: Trade with capacity constraints. European Economic Review, 70, 276-298. https://doi.org/10.1016/j.euroecorev.2014.06.003

Şükrüoğlu, D., \& Nalin, H. T. (2014). The macroeconomic determinants of stock market development in selected European countries: Dynamic panel data analysis. International Journal of Economics and Finance, 6(3), 64-71. https://doi.org/10.5539/ijef.v6n3p64

Switzer, L. N., \& Picard, A. (2016). Stock market liquidity and economic cycles: A non-linear approach. Economic Modelling, 57, 106-119. https://doi.org/10.1016/j.econmod.2016.04.006

Tehrani, R., Ahmadinia, H., \& Hasbaei A. (2011). Analyzing performance of investment companies listed in the Tehran stock exchange by selected ratios and measures. African Journal of Business Management, 5(17), 7428-7439. https://doi.org/10.5897/AJBM11.204

Thamprasert, K., Pastpipatkul, P., \& Yamaka, W. (2018). Interval-valued estimation for the five largest market capitalization stocks in the Stock Exchange of Thailand by Markov-Switching CAPM. In International Econometric Conference of Vietnam (pp. 916-925). https://doi.org/10.1007/978-3-319-73150-6_67

Tsaurai, K. (2018). What Are the Determinants of Stock Market Development in Emerging Markets? Academy of Accounting and Financial Studies Journal.

\section{Copyrights}

Copyright for this article is retained by the author(s), with first publication rights granted to the journal.

This is an open-access article distributed under the terms and conditions of the Creative Commons Attribution license (http://creativecommons.org/licenses/by/4.0/). 